\title{
Carbon dioxide fluxes of soils and mosses in wet tundra of Taimyr Peninsula, Siberia: controlling factors and contribution to net system fluxes
}

\author{
Martin Sommerkorn, Manfred Bölter \& \\ Ludger Kappen
}

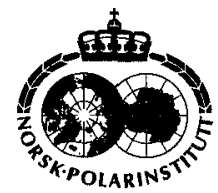

\begin{abstract}
Knowledge of the environmental controls of carbon dioxide fluxes is essential for understanding the dynamics of carbon exchange between ecosystems and atmosphere. In this study we investigated soil respiration and moss photosynthesis as well as their contribution to the net carbon dioxide flux of two different wet tundra systems. During two summers, in situ carbon dioxide fluxes were measured in a tussock tundra and in a low-centre polygonal tundra on Taimyr Peninsula, central Siberia. Measurements were carried out by means of a multichannel gas exchange system. Results show pronounced differences in soil respiration rates as related to microscale topography, mainly due to differences of soil water table and soil temperatures. Modelling of soil respiration for individual microsites revealed differences of process performance with respect to both factors. The wet microsites showed the highest potential regarding an increase of soil respiration rates in warmer and drier climate change scenarios. Another important process compensating the $\mathrm{CO}_{2}$ release from the soil was the photosynthesis of the moss layer, assimilating as much as $51 \%$ to $98 \%$ of the daily amount of carbon dioxide released from wet tundra soils. This result demonstrates the importance of mosses in the context of tundra ecosystem processes. The magnitude of net system fluxes of the whole system at the depression of the polygonal tundra was strongly influenced by changes in soil water table. Consequently, any changes of the hydrology, as anticipated in the context of global change, would effectively alter the carbon balance of wet tundra systems.
\end{abstract}

M. Sommerkorn, M. Bölter \& L. Kappen, Institute for Polar Ecology, Wischhofstr. 1-3, bldg. 12, D-24148 Kiel, Germany.

\section{Introduction}

As a consequence of cold and wet conditions in soils of tundra ecosystems large amounts of carbon are stored below-ground (Post et al. 1982; Gorham 1991). Therefore, the potential for feedback effects on possible changing climatic conditions is an important issue in the study of tundra systems. Soil respiration is the process responsible for the release of carbon from the below-ground store to the atmosphere. Factors controlling soil respiration, however, show pronounced small-scale differences in tundra. The aim of this study was to gain an understanding of the small-scale variability of $\mathrm{CO}_{2}$ fluxes in wet tundra types. Analysing the small- scale patterns of tundra can reveal future perspectives of the ecosystem, because shifts of ecosystem structure and function in response to climate change will occur on the same axis as existing patterns and gradients (Tenhunen, Lange et al. 1992).

The release of carbon dioxide to the atmosphere by soil respiration can be modified to a large extent by the moss layer, which forms an extensive interface (75-100\% coverage) between soil and atmosphere in wet tundra (Shaver \& Chapin 1991). The mosses function as a filter when assimilating $\mathrm{CO}_{2}$ originating from soil respiration. Soil and moss layers are densely interwoven and can therefore not be separated when measuring $\mathrm{CO}_{2}$ fluxes. Consequently, a technique for the in situ 
measurement of the intact soil-moss system had to be developed to assess realistically its $\mathrm{CO}_{2}$ fluxes.

The assessment of ecosystem fluxes is enhanced by understanding the contribution and control of single components of the ecosystem (Tenhunen, Siegwolf et al. 1994). To illustrate this for the case of wet tundra, whole system $\mathrm{CO}_{2}$ fluxes were measured and the contributions of soil and mosses calculated.

\section{Study sites}

Taimyr Peninsula is situated between $70^{\circ} \mathrm{N}$ and $78^{\circ} \mathrm{N}$ and between $86^{\circ} \mathrm{E}$ and $115^{\circ} \mathrm{E}$ in central Siberia. It is characterized by a cold, dry continental climate, with a mean annual temperature of about $-13^{\circ} \mathrm{C}$. The entire area is underlain by permafrost. Taimyr Peninsula shows a sequence of vegetation units from the taiga to the polar desert, covering southern Arctic tundra, typical Arctic tundra, and northern Arctic tundra (Matveyeva 1994).

The intensive study site Lake Labaz is situated at $72^{\circ} 23^{\prime} \mathrm{N}, 99^{\circ} 43^{\prime} \mathrm{E}$ in the North Siberian Lowland and inside the southern Arctic tundra belt at about $50 \mathrm{~m}$ asl. A monthly average of air temperature of $13.8 \mathrm{C}$ for July and an annual precipitation of $243 \mathrm{~mm}$ are recorded at the nearest climate station (Khatanga, about $100 \mathrm{~km}$ east). The gleyic soils of the study area are characterized by thaw depths up to $60 \mathrm{~cm}$ and organic layers up to $30 \mathrm{~cm}$ thick. On the flat and therefore wet habitats which are representative for most of the study area a tussock tundra has developed, dominated by Eriophorum vaginatum, sub-Arctic dwarf shrubs and mosses like Tomentypnum nitens and Drepanocladus uncinatus. $\mathrm{CO}_{2}$ flux measurements were carried out at a moss hummock and an intertussock depression in this type of tundra.

The intensive study site Lake Levinson-Lessing is situated at $74^{\circ} 32^{\prime} \mathrm{N}, 98^{\circ} 36^{\prime} \mathrm{E}$ in a valley of the Byrranga Mountains inside the typical Arctic tundra belt at $40 \mathrm{~m}$ asl. Surrounding mountains reach up to $560 \mathrm{~m}$. Taimyr Lake Station, about $70 \mathrm{~km}$ to the east, records a monthly average air temperature of $6.6^{\circ} \mathrm{C}$ for July and an annual precipitation of $281 \mathrm{~mm}$. In the valley of the study site, organic layers are up to $10 \mathrm{~cm}$ thick and active layer depths do not exceed $30-45 \mathrm{~cm}$. In the extensive flat and wet areas of the valley, low centre polygons are dominant. The diameter of the polygons ranges from 6 to $12 \mathrm{~m}$ and the apices with underlying ice wedges are 10 to $60 \mathrm{~cm}$ high. The wet depressions are dominated by Carex stans and Dupontia fisheri, as well as Drepanocladus revolvens. The apices with the underlying ice wedges are covered by dwarf shrubs like Dryas punctata and a dense moss carpet dominated by Tomentypnum nitens. In this type of tundra, measurements of $\mathrm{CO}_{2}$ fluxes were carried out at the central depression and a low (i.e. about $10 \mathrm{~cm}$ high) apex.

\section{Methods}

Measurements of soil respiration and of the $\mathrm{CO}_{2}$ fluxes of the soil-moss system were carried out by means of a multichannel gas exchange instrumentation (Walz, Germany) operating in dynamic differential mode. A detailed description of the $\mathrm{CO}_{2}$ exchange instrumentation used for the present study can be found in Sommerkorn (1998).

The chamber system for the soil respiration measurements consisted of soil frames permanently anchored in the ground throughout the field season, with non-transparent chambers placed and sealed on the soil frames only for the measuring periods. Up to four chambers with diameters of $19 \mathrm{~cm}$ and $10 \mathrm{~cm}$ were simultaneously in use, each one at one characteristic microsite. The diameter was selected to obtain the highest possible homogeneity in terms of microtopography. To avoid clipping of vascular plants, the chambers were positioned in vegetation gaps. The moss layer was left intact as well.

A transparent, temperature controlled chamber - a modified "Minicuvette System" (Walz, Germany) - served for the continuous in situ recording of the $\mathrm{CO}_{2}$ fluxes of the soil-moss system. The chamber was positioned in gaps between vascular plants and covered a surface area of $56 \mathrm{~cm}^{2}$. A soil frame attached to the chamber was lowered down to the soil water, so that the green parts of the mosses were situated in the transparent part of the chamber. An external control unit adjusted the temperature inside the chamber according to the signal of an external sensor which was placed nearby. Thus, in combination with the dynamic differential mode of the $\mathrm{CO}_{2}$ exchange device a continuous longterm operation under natural conditions was possible, maintaining the moss water content, 


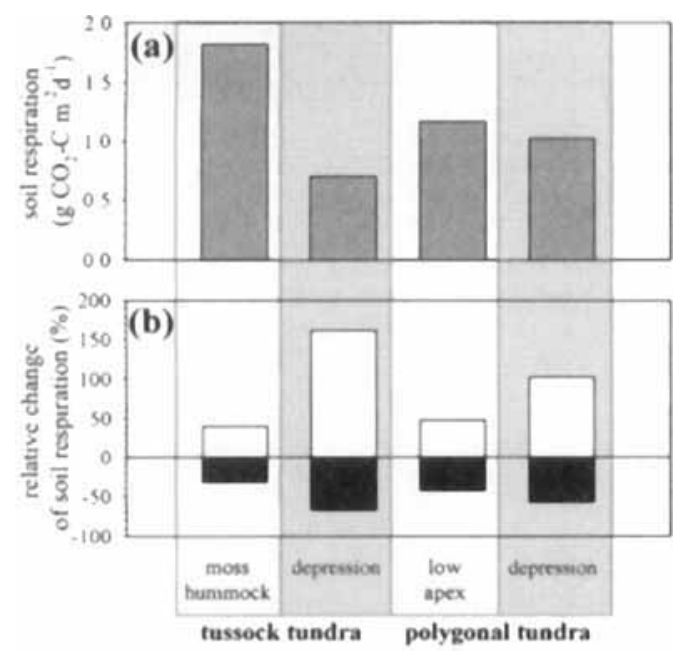

warmer, drier scenario: soil temperature at $2 \mathrm{~cm}$ depth original conditions $+4^{\circ} \mathrm{C}$, soil water table original conditions $-4 \mathrm{~cm}$

colder, wetter scenario: soil temperature at $2 \mathrm{~cm}$ depth original conditions $-4^{\circ} \mathrm{C}$, soil water table original conditions $+4 \mathrm{~cm}$

Fig. 1. Model outputs of (a) soil respiration rates (average daily loss of $\mathrm{CO}_{2}-\mathrm{C}$ ) for the investigated microsites for the period July/August with the original conditions; and (b) relative changes of soil respiration rates compared to the original rates calculated with two different scenarios.

temperature gradient and $\mathrm{CO}_{2}$ concentration of the natural site. In the light, the net flux of the soil-moss system was measured. Every hour the chamber was covered with a dark cloth to analyse the respiration of the soil-moss system. The obtained respiration data points were interpolated and the gross photosynthesis of the mosses was calculated from the respiration value and the net system flux value.

Static chamber measurements of the $\mathrm{CO}_{2}$ fluxes of the whole system (including soil, moss and vascular plants) were carried out at the same plots as used for the determination of soil respiration and the $\mathrm{CO}_{2}$ fluxes of the soil moss system. A $30 \mathrm{~cm}$ high chamber made of acrylic glass could be placed in a water-filled ditch situated on top of a soil frame, covering a surface area of $900 \mathrm{~cm}^{2}$. Measurements for net system flux and system respiration were carried out once an hour over a diurnal course.

Soil microclimate was continuously recorded in $20 \mathrm{~cm}, 10 \mathrm{~cm}, 5 \mathrm{~cm}$ and $2 \mathrm{~cm}$ depth, and at the soil surface. Photosynthetic Photon Flux Density (PPFD) was continuously measured at the level of the moss carpet and above the vascular plant canopy. Depth to water table was measured in holes in the ground. Water content of soil and moss samples was intermittently analysed by means of a moisture analyser (MA3O, Sartorius, Germany). The two data sets for $\mathrm{CO}_{2}$ flux and microclimatic parameters were merged, and the common controlling factors for the $\mathrm{CO}_{2}$ fluxes of all microsites assigned by Spearman rank analysis. To identify spatial differences with respect to the mode of operation of the controlling factors, models describing soil respiration (Oberbauer, Gillespie et al. 1992; Lloyd \& Taylor 1994) as well as moss photosynthesis (Kappen et al. 1995) were individually fitted for each microsite investigated.

Estimation of the contribution of soil and mosses to the $\mathrm{CO}_{2}$ flux of the whole system was performed assuming homogeneity within the area the three different chambers were positioned in (ca. $0.5 \mathrm{~m}^{2}$ ), as supported by observations of the above-ground structure of the particular microsite (depression of the polygonal tundra). The calculations were carried out by applying the models for soil respiration and moss photosynthesis to the microclimatic conditions of the days the whole system experiments were performed.

\section{Results and discussion}

Soil respiration: Previous studies have suggested that control of $\mathrm{CO}_{2}$ efflux from wetland soils is complex and site specific (Svensson 1980; Luken \& Billings 1985; Moore 1986). In this study, soil respiration rates showed wide differences between the microsites investigated (Fig. 1a). At the southern study site, modelled daily means for the period July/August ranged from $2.6 \mathrm{~g}$ $\mathrm{CO}_{2} \mathrm{~m}^{-2} \mathrm{~d}^{-1}$ at the depression of the tussock tundra to $6.7 \mathrm{~g} \mathrm{CO}_{2} \mathrm{~m}^{-2} \mathrm{~d}^{-1}$ at the moss hummock of the tussock tundra. In the polygonal tundra at the northern study site, $\mathrm{CO}_{2}$ was lost from the soil with rates of $3.8 \mathrm{~g} \mathrm{CO}_{2} \mathrm{~m}^{-2} \mathrm{~d}^{-1}$ at the central depression and $4.3 \mathrm{~g} \mathrm{CO}_{2} \mathrm{~m}^{-2} \mathrm{~d}^{-1}$ at the low apex. These values are in the range of those from other studies in similar types of tundra in Alaska (Oberbauer, Oechel et al. 1986; Oberbauer, Tenhunen et al. 1991; Oberbauer, Gillespie et al. 1992). The widest range of daily means in our study was observed in the same type of tundra, and within a distance of about $1 \mathrm{~m}$, highlighting the importance of the microtopographic scale on $\mathrm{CO}_{2}$ fluxes in wetlands, which is 
Table 1. Spearman rank correlations $\left(r_{s}\right)$ for all soil respiration data ( 15 min averages, $n=627$ ) of all investigated sites with microclimatic parameters. ${ }^{*}$ indicates correlation is significantly different from zero at $\mathrm{P}<0.05$.

\begin{tabular}{lccccccc}
\hline & \multicolumn{4}{c}{ Soil temperatures } & & Depth to \\
\cline { 2 - 7 } & Surface & $2 \mathrm{~cm}$ & $5 \mathrm{~cm}$ & $10 \mathrm{~cm}$ & $20 \mathrm{~cm}$ & $\begin{array}{c}\text { Depth to } \\
\text { water table }\end{array}$ & permafrost \\
\hline $\begin{array}{c}\text { Soil respiration, } \\
\text { all data, all sites }\end{array}$ & $* 0.566$ & $* 0.709$ & $* 0.673$ & $* 0.616$ & 0.003 & $*-0.736$ & -0.092 \\
\hline
\end{tabular}

in correspondence with findings of Flanagan \& Bunnel (1980) and Waddington \& Roulet (1996). The explanation for the wide range of soil respiration rates observed over the microtopographic scale in this study is based on the combination of two facts. First, depth to water table and soil temperature at $2 \mathrm{~cm}$ depth explained most of the variations observed in soil respiration (Table 1). Second, the maximum differences in these parameters occurred on the microscale, not between study areas (Table 2). The finding that environmental controls on soil respiration in wet tundra can be uniform over latitudinal and longitudinal gradients has recently been presented by Christensen et al. (1998).

The position of the water table was the primary factor controlling soil respiration at the sites investigated in this study (Fig. 2, Table 1). The water table controlled the baseline of soil respiration while soil temperature determined the variation of soil respiration on this given baseline. The primary role of the soil table in controlling soil respiration, as found in this study, accords with other studies on soil respiration in wet tundra and bog systems (e.g. Peterson et al. 1984; Luken \& Billings 1985; Moore \& Knowles 1989; Oberbauer, Tenhunen et al. 1991; Oberbauer, Gillespie et al. 1992). Billings et al. (1984) presumed that the specific controlling mechanism is oxygen diffusion limitation. This is supported by Whalen et al. (1996), who found that moist tundra soils remain oxygenated down to, or almost to, the water table but show a marked depletion of oxygen at or within $1 \mathrm{~cm}$ of the water table. However, the soil respiration rates observed at the depression of the polygonal tundra (Fig. 2) suggest that even with the water table above the soil surface, considerable soil respiration rates - up to $100 \mathrm{mg} \mathrm{CO}_{2} \mathrm{~m}^{-2} \mathrm{~h}^{-1}$ - may occur.

Soil temperature at $2 \mathrm{~cm}$ depth served best to explain the temperature induced variations of soil respiration. Studies agree that soil temperature close to the soil surface is a better predictor of $\mathrm{CO}_{2}$ efflux from tundra than temperatures of deeper horizons (e.g. Svensson 1980; Luken \& Billings 1985; Moore 1986; Oberbauer, Tenhunen et al. 1991; Oberbauer, Gillespie et al. 1992). This suggests that the majority of $\mathrm{CO}_{2}$ released by soil respiration in tundra originates from the uppermost horizons. As a consequence of both controlling factors, the highest rates of soil respiration in the present study were observed at the more elevated microsites with low water tables and high temperatures in the upper soil horizons; the lowest at the cold depressions with high water table positions (Fig. 1a, Table 2).

Evaluating the relative potential of soil respiration in relation to different scenarios revealed a contrasting pattern (Fig. 1b). The wet and cold microsites showed a much greater relative response to changes in water table position and soil temperature than the drier, warmer microsites, particularly in warmer and drier scenarios. This suggests that the relative potential for feedback effects on possible changing conditions is highest in wet ecosystems. The main factor responsible for this pattern was the strong response of soil respiration to changes in water table close to the

Table 2. Soil temperature at $2 \mathrm{~cm}$ depth and depth to water table for the investigated microsites during the period July/August.

\begin{tabular}{lcccrr}
\hline & \multicolumn{2}{c}{ Tussock tundra } & & \multicolumn{2}{c}{ Polygonal tundra } \\
\cline { 2 - 3 } \cline { 5 - 6 } & Moss hummock & Depression & & Low apex & Depression \\
\hline Mean soil temperature $2 \mathrm{~cm}(\mathrm{C})$ & 11.5 & 7.6 & & 7.3 & 8.7 \\
Mean water table below soil surface $(\mathrm{cm})$ & -13.7 & -3.7 & & -10.7 & -2.4 \\
\hline
\end{tabular}




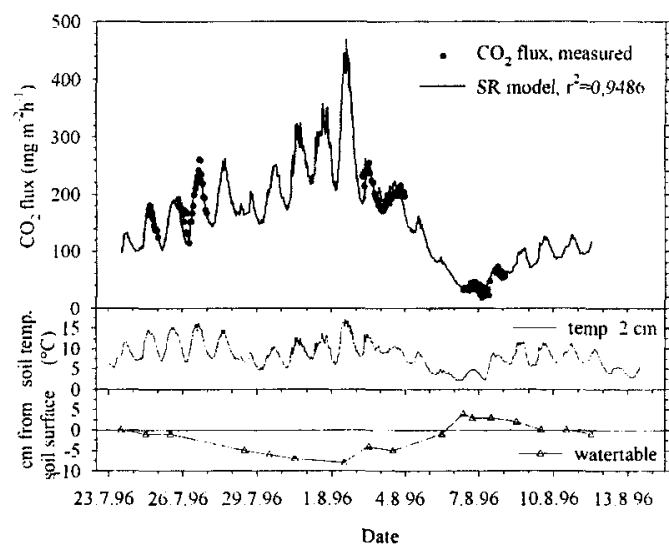

Fig. 2. Measured soil respiration values ( $15 \mathrm{~min}$ averages) and modelled course of soil respiration (SR model). as well as soil temperature at $2 \mathrm{~cm}$ depth and depth to water table at the depression of the polygonal tundra, during the field season at Lake Levinson-Lessing.

soil surface. Moreover, the permanently wet sites showed a more pronounced response to water table changes compared to the more elevated sites. Similar results have been reported by Oberbauer, Gillespie et al. (1992), who, in a gradient study in riparian tundra in Alaska, also found a steeper response of $\mathrm{CO}_{2}$ efflux to changes in water table positions towards the more waterlogged side of the transect. Moore \& Knowles (1989) and Oberbauer, Tenhunen et al. (1991) assume these differences to be based on the physical properties of the soils.

$\mathrm{CO}_{2}$ fluxes of the soil-moss system: At the sites investigated in this study, moss coverage ranged from $71-100 \%$. The net flux of the soil-moss system was characterized by a phase-shift be-

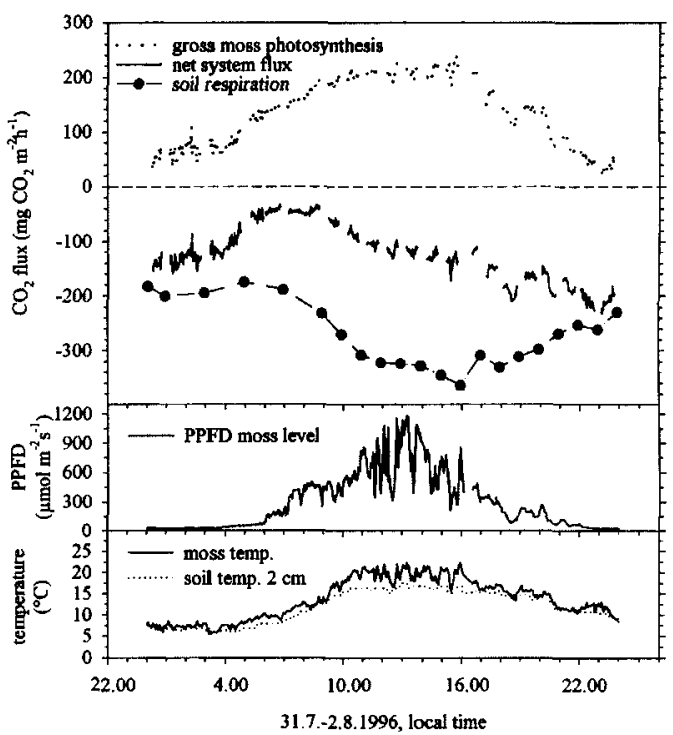

Fig. 3. $\mathrm{CO}_{2}$ fluxes (net system flux, soil respiration, gross photosynthesis) and microclimatic conditions of the soil-moss system during a diurnal experiment on 1.8 .1996 at the depression of the polygonal tundra. Depth to water table was $7 \mathrm{~cm}$ over the experimental period. Carbon losses of the soil-moss system are shown as negative fluxes, carbon gains as positive fluxes.

tween soil and moss respiration and moss photosynthesis (Fig. 3). During the early morning, the mosses were already able to assimilate considerably with low irradiance levels due to their low light saturation levels and high photosynthetic efficiency, whereas respiration was low due to low temperatures. Consequently, the $\mathrm{CO}_{2}$ losses of the soil-moss system were lowest during this time of the day, but highest in the evening,

Table 3. Soil and moss respiration, gross moss photosynthesis, net system flux of the soil-moss system $\left(\mathrm{g} \mathrm{CO}_{2}-\mathrm{C} \mathrm{m}^{-2} \mathrm{~d}^{-1}\right)$, and percent reduction of soil and moss respiration by gross moss photosynthesis, for selected diumal courses of the investigated microsites.

\begin{tabular}{|c|c|c|c|c|}
\hline & \multicolumn{2}{|c|}{ Tussock tundra } & \multicolumn{2}{|c|}{ Polygonal tundra } \\
\hline & Moss hummock & Depression & Low apex & Depression \\
\hline $\begin{array}{l}\text { Respiration of the soil-moss system } \\
\qquad\left(\mathrm{g} \mathrm{CO}_{2}-\mathrm{C} \mathrm{m}^{-2} \mathrm{~d}^{-1}\right)\end{array}$ & -2.58 & -0.52 & -1.55 & -1.07 \\
\hline $\begin{array}{l}\text { Gross photosynthesis of the mosses } \\
\left(\mathrm{g} \mathrm{CO}_{2}-\mathrm{C} \mathrm{m}^{-2} \mathrm{~d}^{-1}\right)\end{array}$ & 1.31 & 0.33 & 1.53 & 0.68 \\
\hline $\begin{array}{l}\text { Net flux of the soil-moss system } \\
\qquad\left(\mathrm{g} \mathrm{CO}_{2}-\mathrm{C} \mathrm{m}^{-2} \mathrm{~d}^{-1}\right)\end{array}$ & -1.27 & -0.19 & -0.02 & -0.38 \\
\hline $\begin{array}{l}\text { Reduction of soil and moss respiration by } \\
\text { gross moss photosynthesis (\%) }\end{array}$ & 51 & 64 & 99 & 64 \\
\hline
\end{tabular}




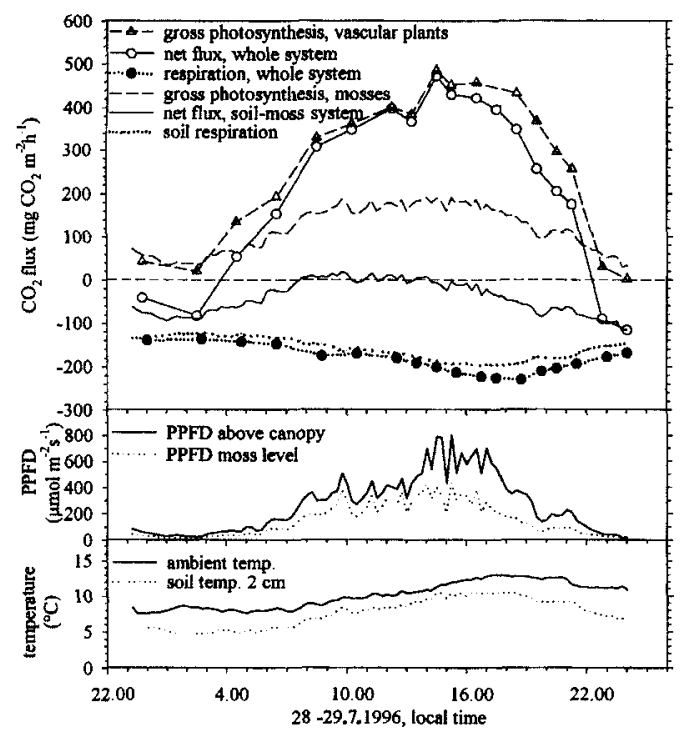

Fig. 4. $\mathrm{CO}_{2}$ fluxes of the whole system and the subsystems, as well as microclimatic conditions at the depression of the polygonal tundra during a diurnal experiment on 29.8.1996. Depth to water table was $4 \mathrm{~cm}$. Carbon losses of the system are shown as negative fluxes, carbon gains as positive fluxes.

when the light ceased but temperatures were still higher. $\mathrm{A} \mathrm{CO}_{2}$ enriched immediate environment of the photosynthetic active parts of the mosses is inferred from the observation that soil respiration exceeded moss photosynthesis during extended periods of the day, supporting the findings of Sveinbjörnsson \& Oechel (1992).

The soil-moss systems of all microsites inves- tigated showed a net loss of $\mathrm{CO}_{2}$ to the atmosphere on the daily scale (Table 3 ). The absolute net effluxes ranged from $0.02 \mathrm{~g} \mathrm{CO}_{2}-\mathrm{C} \mathrm{m}^{-2} \mathrm{~d}^{-1}$ to $1.27 \mathrm{~g} \mathrm{CO}_{2}-\mathrm{C} \mathrm{m}^{-2} \mathrm{~d}^{-1}$. Relative reductions of the $\mathrm{CO}_{2}$ efflux originating from soil respiration by the photosynthesis of the mosses ranged from $51 \%$ (moss hummock of the tussock tundra) to as much as $99 \%$ (low apex of the polygonal tundra) on a daily scale. These results clearly show the importance of moss photosynthesis in the context of tundra ecosystem $\mathrm{CO}_{2}$ fluxes. Neither the relative reduction of the $\mathrm{CO}_{2}$ efflux nor the daily means of the net $\mathrm{CO}_{2}$ flux of the soil-moss system could be linked to an overall pattern. Both were determined by the microsite dependent interplay of microclimatic parameters. Most important, the mosses were fully hydrated throughout the field season at the microsites investigated because the water table was close to the surface. Lower water table positions could lower moss photosynthesis due to lower moss water contents, which would cause increased net $\mathrm{CO}_{2}$ efflux of the soil-moss system.

Whole-system $\mathrm{CO}_{2}$ fluxes: The whole system (soil, moss, vascular plants) of the wet depression of the polygonal tundra at Lake Levinson-Lessing was a strong sink for atmospheric carbon during the experimental periods (Fig. 4). Carbon was accumulated at rates of 1.3 and $1.55 \mathrm{~g} \mathrm{CO}_{2}-\mathrm{C} \mathrm{m}^{-2} \mathrm{~d}^{-1}$ (Table 4). This is in the range of the maximum daily accumulation rates Tenhunen, Lange et al. (1992) calculated for the tussock tundra of Imnavait Creek, Alaska. The bulk of the $\mathrm{CO}_{2}$ gain in our study was

Table 4. Contribution of the subsystems to the total daily net system flux $\left(\mathrm{g} \mathrm{CO}_{2}-\mathrm{C} \mathrm{m}^{-2} \mathrm{~d}^{-1}\right)$ and microclimatic conditions for two diurnal experiments (29.7.1996 and 9.8.1996) at the depression microsite of the polygonal tundra.

\begin{tabular}{|c|c|c|}
\hline Polygonal tundra, depression & $\begin{array}{c}29.7 .1996 \\
\text { (experiment 1) } \\
\left.g C O_{2} \mathrm{C} \mathrm{m}^{-2} d^{-1}\right)\end{array}$ & $\begin{array}{c}9.8 .1996 \\
\text { (experiment 2) } \\
g C \mathrm{CO}_{2} \mathrm{C} m^{-2} d^{-1} \text { ) }\end{array}$ \\
\hline Net system flux & 1.30 & 1.55 \\
\hline Gross photosynthesis vascular plants & 1.69 & 1.78 \\
\hline Gross photosynthesis mosses & 0.76 & 0.62 \\
\hline Net flux soil-moss system & -0.28 & -0.14 \\
\hline Whole system respiration & -1.16 & -0.84 \\
\hline Above ground respiration vascular plants & -0.12 & -0.07 \\
\hline Soil respiration & -1.04 & -0.77 \\
\hline Water table ( $\mathrm{cm}$ below soil surface) & -4 & -1 \\
\hline Mean air temperature $2 \mathrm{~m}\left({ }^{\circ} \mathrm{C}\right)$ & 10.1 & 7.0 \\
\hline Mean moss temperature $\left({ }^{\circ} \mathrm{C}\right)$ & 8.6 & 8.9 \\
\hline Mean soil temperature $2 \mathrm{~cm}\left({ }^{\circ} \mathrm{C}\right)$ & 7.5 & 8.5 \\
\hline Daily total PPFD $2 \mathrm{~m}\left(\mathrm{~mol} \mathrm{~m}^{-2} \mathrm{~d}^{-1}\right)$ & 22.38 & 20.50 \\
\hline daily total PPFD moss level $\left(\mathrm{mol} \mathrm{m}^{-2} \mathrm{~d}^{-1}\right)$ & 12.44 & 10.04 \\
\hline
\end{tabular}


contributed by the vascular plants; mosses accounted for 26 and $31 \%$ of the total assimilation. The observation that moss photosynthetic rates exceeded those of vascular plants during nights can be explained by the difference between vascular plant and moss photosynthesis in response to low light levels. During the two diurnal experiments, 66 and $74 \%$ of the respiration of the whole system was compensated for by moss photosynthesis. Thus, also with respect to whole system fluxes, moss photosynthesis had an important effect on the $\mathrm{CO}_{2}$ efflux from the depression of the polygonal tundra.

The contribution of the above-ground portion of the vascular plants to the total system respiration was only $10 \%$. This comparatively low value reflects the fact that the below ground biomass at the depression of the polygonal tundra contributed $98 \%$ of the total biomass.

The major factor controlling the net system $\mathrm{CO}_{2}$ flux of the whole system at the depression of the polygonal tundra in this study was position of the water table. With a water table at $1 \mathrm{~cm}$ below soil surface (soil respiration $0.77 \mathrm{~g} \mathrm{CO}_{2}-\mathrm{C} \mathrm{m}^{-2} \mathrm{~d}^{-1}$ ). the total carbon gain of the system was $1.55 \mathrm{~g} \mathrm{CO}_{2}-\mathrm{C} \mathrm{m}^{-2} \mathrm{~d}^{-1}$, whereas at a water table position of $4 \mathrm{~cm}$ below soil surface (soil respiration $1.04 \mathrm{~g} \mathrm{CO}_{2}-\mathrm{C} \mathrm{m}^{-2} \mathrm{~d}^{-1}$ ), only $1.3 \mathrm{~g} \mathrm{CO}_{2-}$ $\mathrm{C} \mathrm{m}^{-2} \mathrm{~d}^{-1}$ was gained (Table 4). The effect of water table induced variations in soil respiration on diurnal tundra net system flux may be visualized best as a shift of a zero line. The zero line, on which the carbon gain by assimilation can add on, decreases with lower water tables (due to higher soil respiration rates), and increases with higher water tables (due to lower soil respiration rates). Consequently, any changes of the hydrology, as anticipated in the context of global climatic change, would lead to shifts of wet tundra systems source/sink action for atmospheric $\mathrm{CO}_{2}$ through altered net system fluxes. Oberbauer, Cheng et al. (1996) showed such zero point shifts - due to changes in soil water table and soil temperature to be on the same order of magnitude as day to day variations of assimilation rates due to aboveground climatic effects. Oechel et al. (1993) came to similar conclusions in a study in Alaskan tundra, suggesting that not temperature changes but hydrological changes were responsible for altered net season carbon exchange.

Acknowledgements. - This study was part of the GermanRussian project "Environmental Development of Central
Siberia during Late Quaternary" and was funded by the German Ministry of Science (BmBF), grant 03PLO14B.

\section{References}

Billings, W. D., Peterson, K. M.. Luken, J. O. \& Mortensen, D. A. 1984: Interaction of increasing atmospheric carbon dioxide and soil nitrogen on the carbon balance of tundra microcosms. Oecologia 65, 26-29.

Christensen, T. R.. Jonasson, S., Michelsen, A., Callaghan, T. V. \& Havström, M. 1998: Environmental controls on soil respiration in the Eurasian and Greenlandic Arctic. $J$. Geophys. Res. I03(D22), 29015-29021.

Flanagan, P. W. \& Bunnel, F. L. 1980: Microflora activities and decomposition. Pp. 291-334. In J. Brown et al. (eds.): An Arctic ecosystem: the coastal tundra at Barrow, Alaska. Pp. 291-334. Stroudsberg, PA: Dowden. Hutchinson and Ross.

Gorham, E. 1991: Northern peatlands: role in the carbon cycle and probable response to climate warming. Ecol. Appl. I. 182-195.

Kappen, L.. Sommerkorn, M. \& Schroeter, B. 1995: Carbon acquisition and water relations of lichens in polar regions potentials and limitations. Lichenologist 27(6), 531-545.

Lloyd. J. \& Taylor. J. A. 1994: On the temperature dependence of soil respiration. Funct. Ecol. 8, 315-323.

Luken, J. O. \& Billings, W. D. 1985: The influence of microtopographic heterogeneity on carbon dioxide efflux from a subarctic bog. Holarctic Ecol. 8(4). 306-312.

Matveyeva. N. V. 1994: Floristic classification and ecology of tundra vegetation of the Taimyr Peninsula, northern Siberia. J. Veg. Sci. 5, 818-828.

Moore, T. R. 1986: Carbon dioxide evolution from subarctic peatlands in eastern Canada. Arct. Alp. Res. 18(2), 189-193.

Moore, T. R. \& Knowles, R. 1989: The influence of water table levels on methane and carbon dioxide emissions from peatland soils. Can. J. Soil Sci. 69, 33-38.

Oberbauer, S. F., Cheng, W., Gillespie, C. T., Ostendorf, B. Sala, A., Gebauer, R., Virginia, R. A. \& Tenhunen. J. D. 1996: Landscape patterns of carbon dioxide exchange in tundra ecosystems. In J. F. Reynolds \& J. D. Tenhunen (eds.): Landscape function and disturbance in Arctic ecosystems. Ecological Studies 120. Pp. 223-256. Berlin: Springer.

Oberbauer, S. F., Gillespie, C. T., Cheng, W., Gebauer. R., Sala Serra. A. \& Tenhunen, J. D. 1992: Environmental effects on $\mathrm{CO}_{2}$ eftlux from riparian tundra in the northern foothills of the Brooks Range, Alaska. USA. Oecologia 92, 568-577.

Oberbauer, S. F., Oechel, W. C. \& Riechers, G. H. 1986: Soil respiration of Alaskan tundra at elevated atmospheric carbon dioxide concentrations. Plant and Soil 96, 145-148.

Oberbauer, S. F.. Tenhunen, J. D. \& Reynolds, J. F. 1991: Environmental effects on $\mathrm{CO}_{2}$ efflux from water track and tussock tundra in arctic Alaska, U.S.A. Arct. Alp. Ress. 2312). 162-169

Oechel. W. C.. Hastings, S. J., Vourlitis, G., Jenkins, M. Riechers, G. \& Grulke, N. 1993: Recent change of Arctic tundra from a net carbon sink to a source. Nature 361 . 520-523.

Peterson, K. M.. Billings, W. D. \& Reynolds, D. N. 1984: Influence of water table and atmospheric $\mathrm{CO}_{2}$ concentration on the carbon balance of Arctic tundra. Arct. Alp. Res. 16(3), $331-335$ 
Post, W. M., Emanuel, W. R., Zinke, P. J. \& Stangenberger, A. G. 1982: Soil carbon pools and world life zones. Nature 298, 156-159.

Shaver, G. R. \& Chapin, F. S. III 1991: Production: biomass relationships and element cycling in contrasting Arctic vegetation types. Ecol. Monogr. 61, 1-31.

Sommerkorn, M. 1998: Patterns and controls of $\mathrm{CO}_{2}$ fluxes in wet tundra types of the Taimyr Peninsula, Siberia - the contribution of soils and mosses. Dissertation, University of Kiel, Germany. Also published in Reports on Polar Research 298. Bremerhaven: Alfred Wegener Institute for Polar and Marine Research.

Sveinbjörnsson, B. \& Oechel, W. C. 1992: Controls on growth and productivity of bryophytes: environmental limitations under current and anticipated conditions. In J. W. Bates \& A. M. Farmer (eds.): Bryophytes and lichens in a changing environment. Pp. 77-102. Oxford: Clarendon Press.

Svensson, B. H. 1980: Carbon dioxide and methane fluxes from the ombotrophic parts of a subarctic mire. In M. Sonesson (ed.): Ecology of a subarctic mire. Ecological Bulletins 30. Pp. 235-250. Stockholm: Swedish Natural Science Research Council.
Tenhunen, J. D., Lange, O. L., Hahn, S., Siegwolf, R. \& Oberbauer, S. F. 1992: The ecosystem role of poikilohydric tundra plants. In F. S. Chapin III et al. (eds.): Arctic ecosystems in a changing climate. Pp. 213-237. San Diego: Academic Press.

Tenhunen, J. D., Siegwolf, R. T. W. \& Oberbauer, S. F. 1994: Effects of phenology, physiology, and gradients in community composition, structure, and microclimate on tundra ecosystem $\mathrm{CO}_{2}$ exchange. In E. D. Schulze \& M. M. Caldwell (eds.): Ecophysiology of photosynthesis. Ecological Studies 120. Pp. 431-460. New York: Springer.

Waddington, J. M. \& Roulet, N. T. 1996: Atmosphere-wetland carbon exchanges: scale dependency of $\mathrm{CO}_{2}$ and $\mathrm{CH}_{4}$ exchange on the developmental topography of a peatland. Glob. Biogeochem. Cycles 10(2), 233-245.

Whalen, S. C., Reeburgh, W. S. \& Reimers, C. E. 1996: Control of methane emissions by microbial oxidation. In J. F. Reynolds \& J. D. Tenhunen (eds.): Landscape function and disturbance in Arctic ecosystems. Ecological Studies 120. Pp. 257-274. Berlin: Springer. 